\title{
MINERALOGICAL CHARACTERIZATION OF CHRYSOTILE FROM BOGOSLOVEC, NORTH MACEDONIA
}

\author{
Tena Šijakova-Ivanova, Ivan Boev, Đorđi Dimov \\ Faculty of Natural and Technical Sciences, "Goce Delčev" University in Štip, \\ Blvd. Krste Misirkov 10-A, P.O. Box 201, 2001 Štip, North Macedonia \\ tena.ivanova@ugd.edu.mk
}

\begin{abstract}
A b s t r a ct: This paper presents the results of an investigation of mineralogical and chemical characteristics of chrysotile from Bogoslovec locality. Investigated samples were analyzed by SEM-EDS and XRD methods. Chrysotile is a member of the serpentine group, occurring in bundles of parallel finers, with random orientation about the finer axis. Chrysotile occurs as compact veins in the serpentinites. Sometimes finer veins split up in several smaller veins or coalesce and form a larger vein. The fibers are oriented perpendicular to the vein walls. Individual chrysotile finers are white and silky, but the colour of the aggregate in veins is usually light yellow to light green. Chrysotile veins are wide up $99 \mu \mathrm{m}$ to a few millimeters. The development of chrysotile veins illustrates the mobility of the major elements $\mathrm{Mg}$, Fe and Si during serpentinization. The luster is silky. Crystal system is monoclinic, point group $2 / \mathrm{m}$. Streak is white. Fibrous crystals of chrysotile from Bogoslovec are with different size (long from 17 to $390 \mu \mathrm{m}$ and width from $0.35 \mu \mathrm{m}$ on individual fibers and $30 \mu \mathrm{m}$ on bundles). In examined samples from Bogoslovec have substitution of $\mathrm{Mg}^{2+} \rightarrow \mathrm{Fe}^{2+}$. Concentration of $\mathrm{Fe}^{2+}$ is in range up 0.52 to $2.68 \mathrm{wt} \%$. The unit cell parameters obtained using the main reflection lines of $\mathrm{X}$-ray diffraction are: $\mathrm{a}=5.330 \AA ; \mathrm{b}=9.156 \AA ; \mathrm{c}=14.665 \AA ; \beta=93.432^{\circ} ; \mathrm{V}=714.550 \AA^{3}$
\end{abstract}

Key words: chrysotile, SEM-EDS, XRD

\section{INTRODUCTION}

Chrysotile is a fibrous mineral that belongs to the serpentine mineral group. All serpentine group minerals share the same chemical composition $\left(\mathrm{Mg}_{3} \mathrm{Si}_{2} \mathrm{O}_{5}(\mathrm{OH})_{4}\right)$ but they have different crystal structures. Chrysotile polytypes are: clinochrysotile (monoclinic), orthochrysotile (orthorhombic), parachrysotile (orthorhombic). Clinochrysotile represents almost all of the known chrysotile specimens. Orthochrysotile is rare and parachrysotile is very rare. Chrysotile occurs as cross-cutting veins in serpentinized rocks. Serpentinization is a hydrothermal metamorphic process that affects magnesiumrich igneous rocks like peridotite and pyroxenite. The published papers for Bogoslovec refer to the geology of this locality, while mineralogical characteristics on chrysotile are not been specified in none of them.

\section{Geological setting}

The Bogoslovec locality is situated $10 \mathrm{~km}$ west of Štip. In the geological setting of this area, several characteristic types of rocks have been identified, such as: sands, clays and gravel, marl, limestone and mudstone, conglomerates, gabbro and serpentinites (Figure 1). The first data on geological research at the locality of Bogoslovec are given by Pavlovik (1951) and Adžigogov (1967). In Bogoslovec locality serpentinite are intersect with older metamorphic quartz-porphyry, while these are intersecting with amphibolic gabbro and vein of biotite- granites. There is insufficient data on the age of serpentinites. However, they are the part of the serpentinites that can be found in the Vardar zone which have Paleozoic age. The serpentinites are strongly slate, crushed and cleavage. Cleavage is parallel with tectonic ruptures.

Serpentinites has green to greenish-black colour, massive texture and mesh structure. They are composed of antigorite mass intersecting with chrysotile veins. Magnetite and chromite appear as accessory minerals. The chrysotile fibers that are visible to the naked eye are composed of hundreds of thousands of monofibers called fibrils in closepacked, parallel arrangement. The fibers are oriented perpendicular to the walls of the vein. 


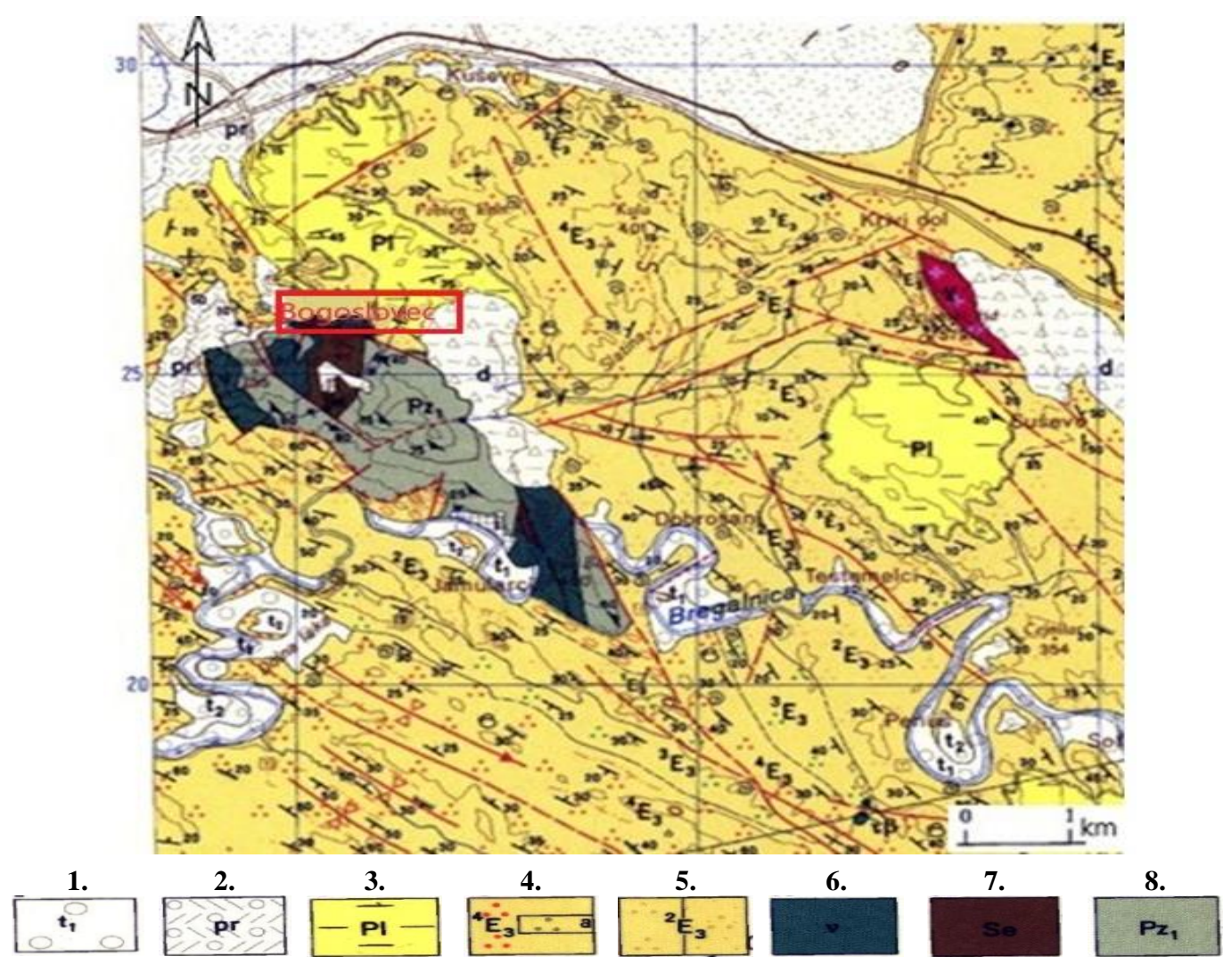

Fig. 1. Geological map of the Bogoslovec locality (Dumurdžanov et al., 1965-68), $R=1: 100000$

Legend: 1. lower river terrace; 2; proluvium; 3. sands, clays and gravel; 4. upper zone of flysch: Mudstone and sandstone, a) marl, limestone and mudstone; 5. lower zone of flysch: a) gray sandstone and purple clay, b) conglomerates, sandstone and clay; 6. gabbro; 7. Serpentinite; 8 . indeterminate ancient paleozoic, slate, quarzporphyry and marble

\section{SAMPLING AND METHODS}

Several samples were taken from different parts of the Bogoslovec locality. Five of them were selected for our investigation. For reliable characterization of the mineral species in our research following analytical methods were used: SEM-EDS, and XRD. The use of these two methods showed that they are very useful methods for rapid mineral analysis contributing important analytical information.

Scanning electron microscopy (SEM) analyses and electron micro-photographs were conducted using a VEGA3LMU scaning electron microscopy (SEM). The study utilized semi-quantitative analysis using internal standards. High-resolution field emission SEM allows observation and investigation of a very fine microarea in situ. The samples were covered with gold before analysis in order to provide conductivity of sample.

XRD analyses were carried by conventional X-ray diffraction (XRD) techniques on bulk samples used a (Shimadzu) XRD-6100, diffractometer with $\mathrm{Cu}(1.54060 \AA)$ radiation operating at $40 \mathrm{kV}$ and $30 \mathrm{~mA}$. The powdered sample was scanned over the $5-80^{\circ}$ range with step size of $0.02^{\circ}$ and scanning speed of $1.2^{\circ} / \mathrm{min}$. The analyzed material is finely ground, homogenized, and average bulk composition is determined. The most intense registered maxima in the studied powder diagrams were compared with the corresponding diagrams from PDF-2 software. Unit Cell software (Tim Holland \& Simon Redfern, 1997, new version Apr 2006) was used for calculation on unit cell data.

\section{RESULTS AND DISCUSSION}

Macroscopic features on serpentinities and chrysotile from the Bogoslovec locality are given in Figure 2. Serpentinities have green colour, massive texture and mesh structure. They are composed of antigorite mass interscting with chrysotile veins. Chrysotile veins are wide up $99 \mu \mathrm{m}$ to a few millimeters. 


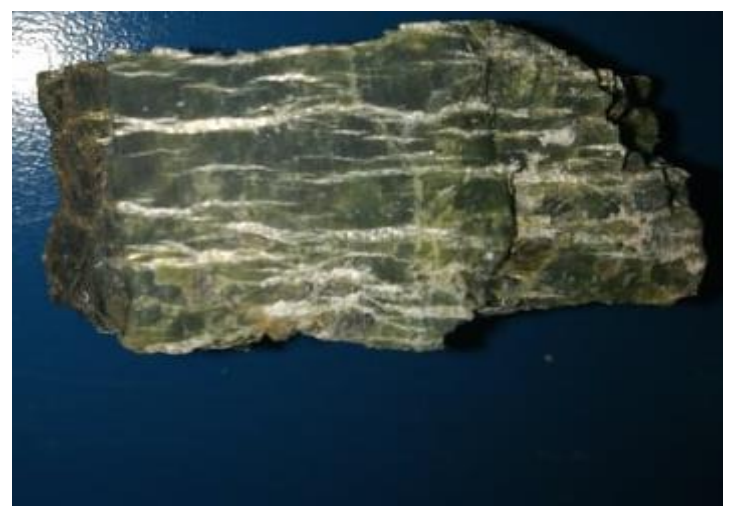

a) Chrysotile vein (sample 1)

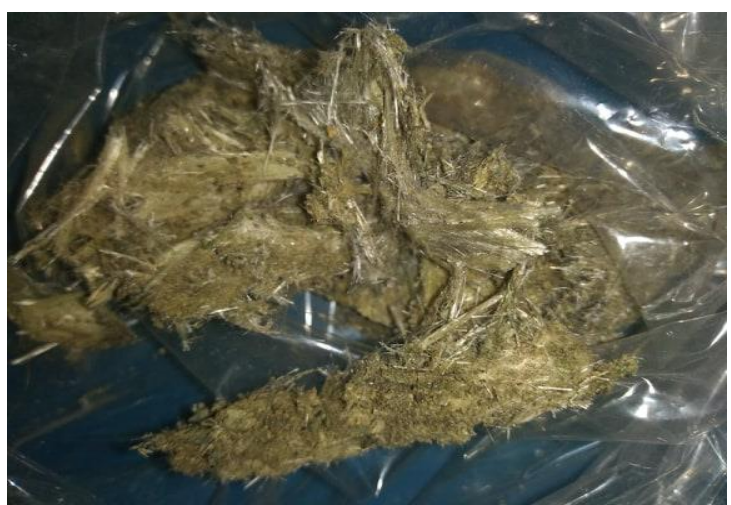

c) Chrysotile fibers (sample 3)

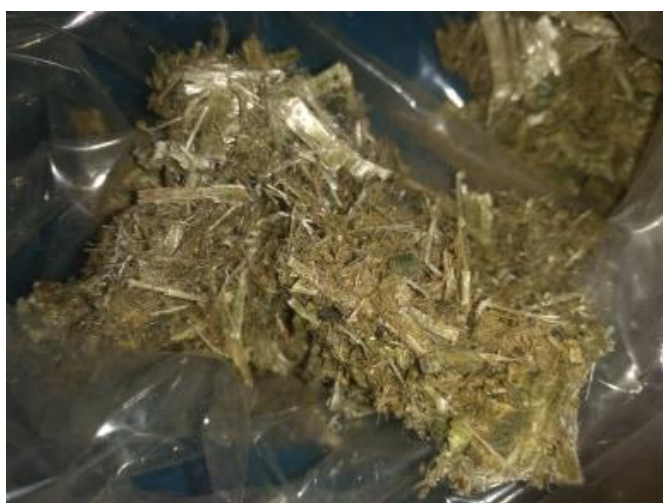

b) Chrysotile fibers (sample 2)

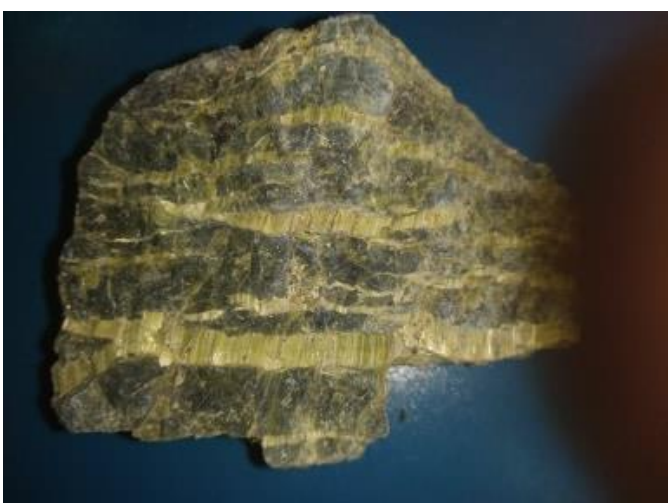

d) Chrysotile vein (sample 4)

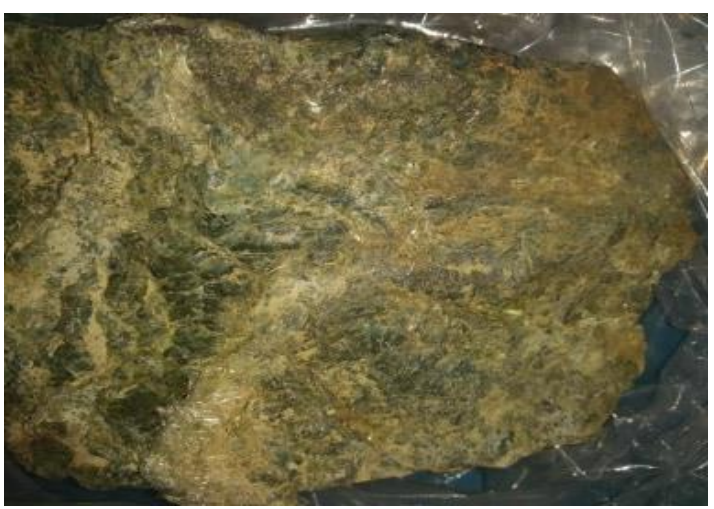

e) Chrysotile fibers (sample 5)

Fig. 2. Chrysotile fibers and veins from Bogoslovec

Individual chrysotile fibers are white and silky, but the colour of the aggregate in veins is usually light yellow to light green. Chrysotile fibers have a higher tensile strength than other asbestos minerals, but they are less acid-resistant than the fibrous amphiboles.

While amphibole fibers are generally harsh, most chrysotile fibers are soft, although fibers displaying intermediate properties also occur. Harshness has been reported to be related to the water content of the fiber, i.e. the higher the water content the "softer" the fiber (Woodroofe, 1956).
Harsh chrysotile fibers tend to be straighter and less flexible than the soft fibers. The mineralogy and properties of chrysotile have been summarized by Wicks $(1979,1988)$, Pooley (1987), and Langer \& Nolan (1994).

SEM image and EDX spectrum for chrysotile in sample 1 are given in Figure 3 and chemistry is given in Table 1. From Table 1 can be seen that there is a presence of $\mathrm{Fe}$ in range $0.88-1.29 \mathrm{wt} \%$. Chrysotile fibers from sample 1 are long $40-390 \mu \mathrm{m}$ and wide from $0.78 \mu \mathrm{m}$ on individual fibers to 30 $\mu \mathrm{m}$ on bundles. 


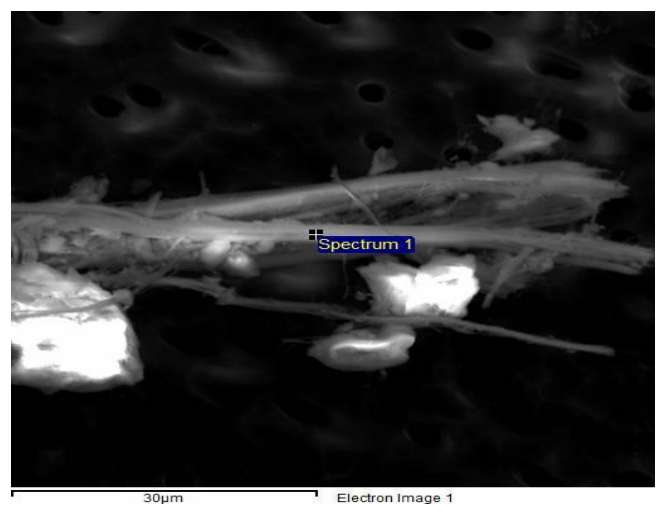

a) SEM image of chrysotile (analysis 1)

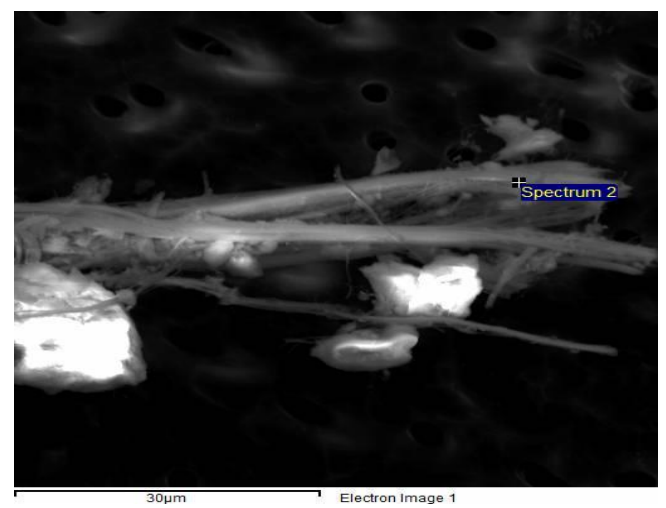

c) SEM image of chrysotile (analysis 2)

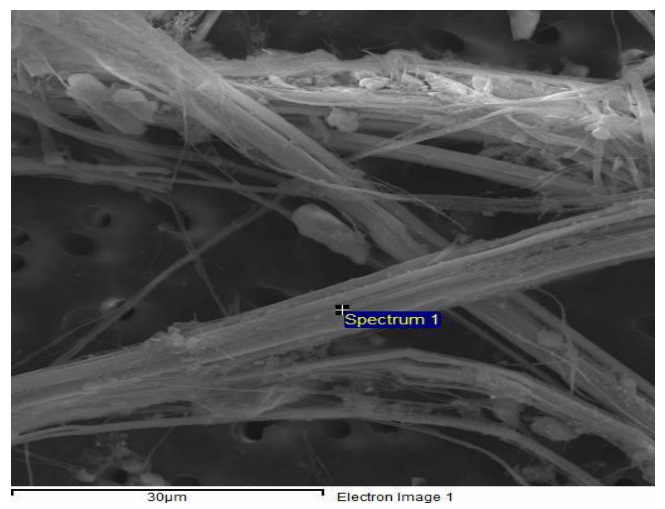

e) SEM image of chrysotile (analysis 3)

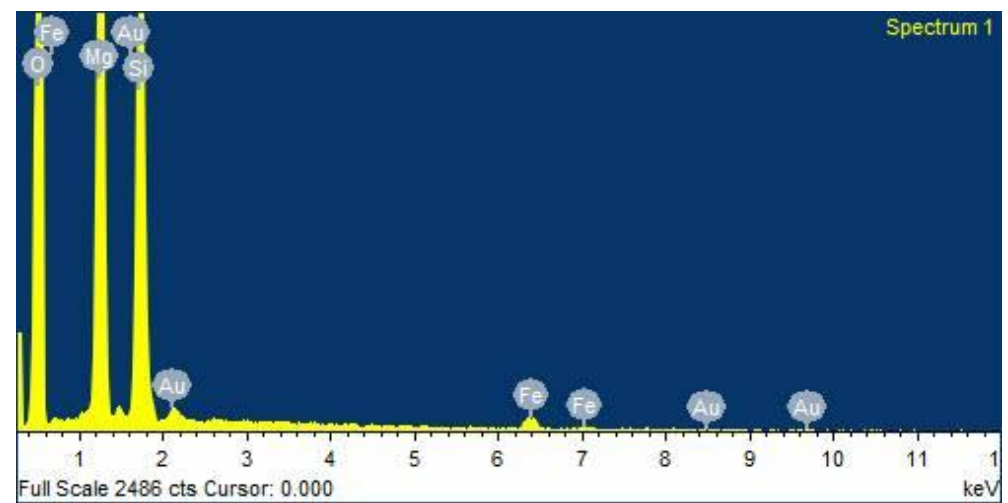

b) EDX of chrysotile (analysis 1)

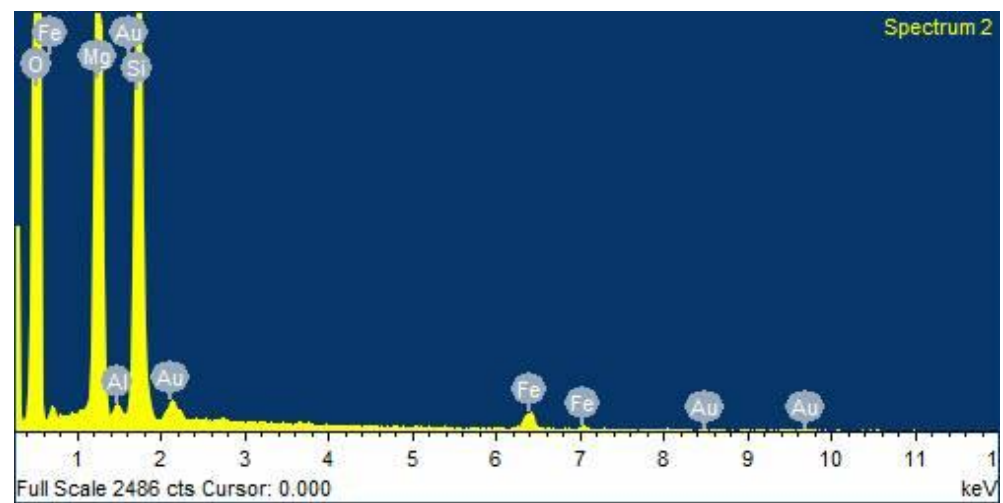

d) EDX of chrysotile (analysis 2)

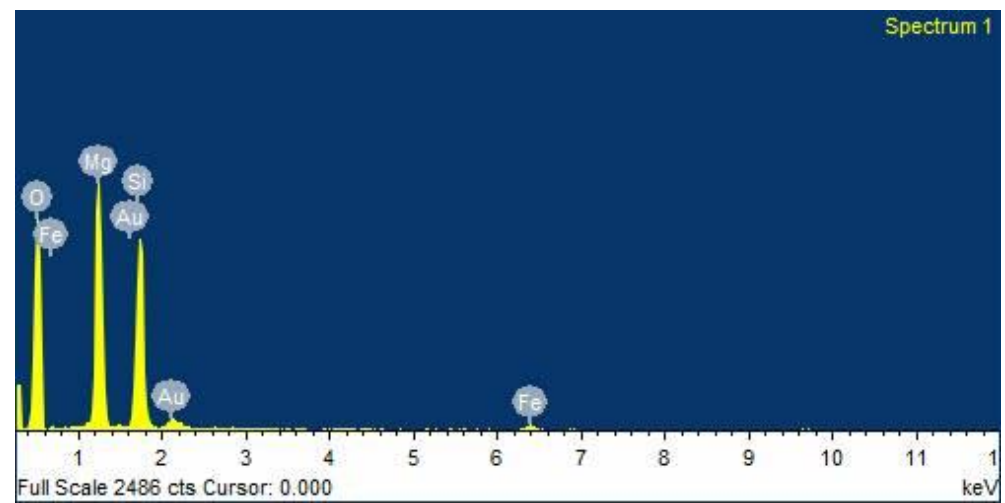

f) EDX of chrysotile (analysis 3)

Fig. 3. SEM image and EDX spectrum of chrysotile from sample 1

SEM image and EDX spectrum for sample 2 are given in Figure 4 and chemistry is given in Table 1. From Table 1 can be seen that there is a presence of Fe in range $0.52-0.56 \mathrm{wt} \%$.

Chrysotile fibers are long 17-136 $\mu \mathrm{m}$ and wide from $0.92 \mu \mathrm{m}$ on individual fibers to $7 \mu \mathrm{m}$ on bundles.

SEM image and EDX spectrum for sample 3 are given in Figure 5 and chemistry is given in Table
1. From Table 1 can be seen that there is a presence of Fe in range 0.90-2.68 wt\%.

Chrysotile fibers are long $33-191 \mu \mathrm{m}$ and wide from $2 \mu \mathrm{m}$ on individual fibers to $8 \mu \mathrm{m}$ on bundles.

SEM image and EDX spectrum for sample 4 are given in Figure 6 and chemistry is given in Table 2. From Table 2 can be seen that there is a presence of $\mathrm{Fe} 0.87 \mathrm{wt} \%$ only in one spectar. Chrysotile fibers are long $17-116 \mu \mathrm{m}$ and wide from $0.35 \mu \mathrm{m}$ on individual fibers to $5 \mu \mathrm{m}$ on bundles. 


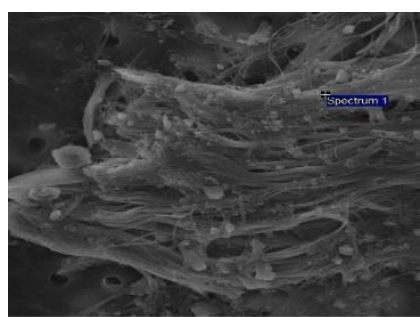

a) SEM image of chrysotile (analysis1)

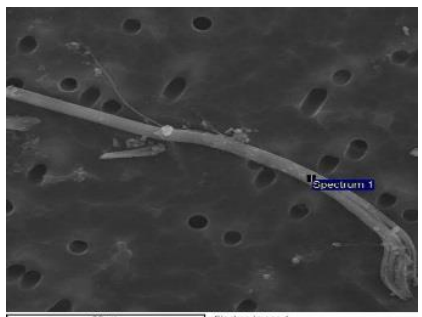

c) SEM image of chrysotile (analysis 2)

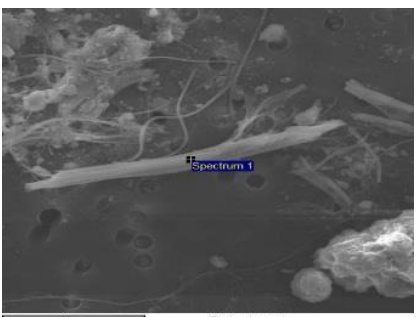

e) SEM image of chrysotile (analysis 3)

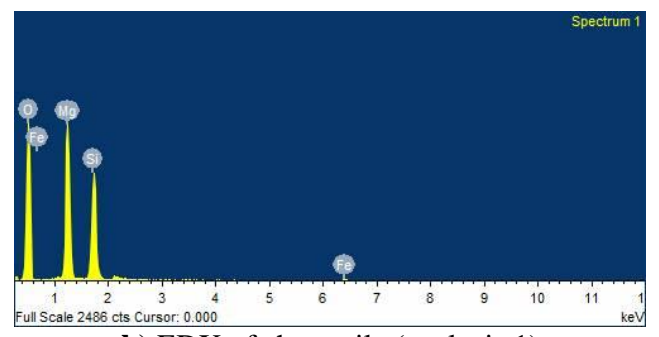

b) EDX of chrysotile (analysis 1)

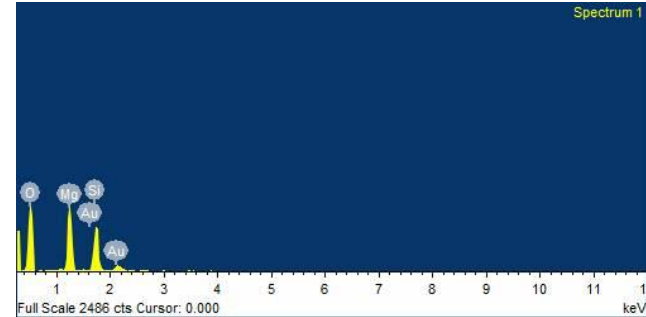

d) EDX of chrysotile (analysis 2)

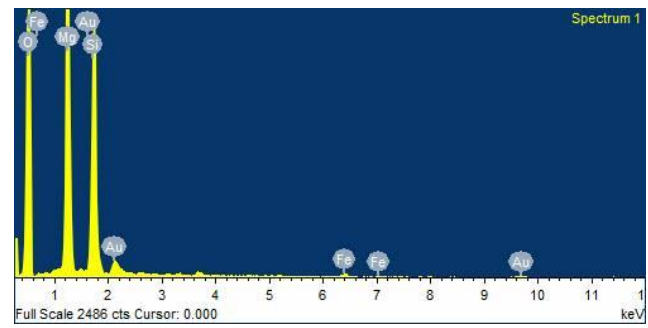

EDX of chrysotile (analysis 3)

Fig. 4. SEM image and EDX spectrum of chrysotile from sample 2

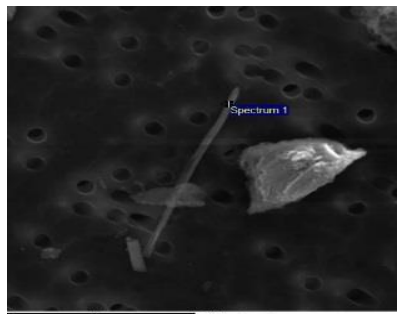

a) SEM image of chrysotile (analysis 1 )

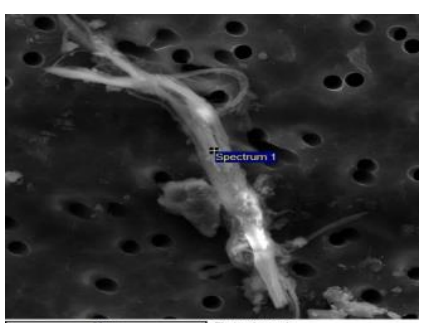

c) SEM image of chrysotile (analysis 2)

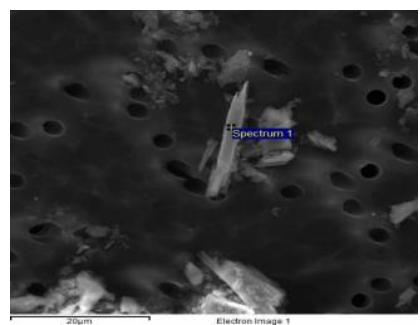

e) SEM image of chrysotile (analysis 3)

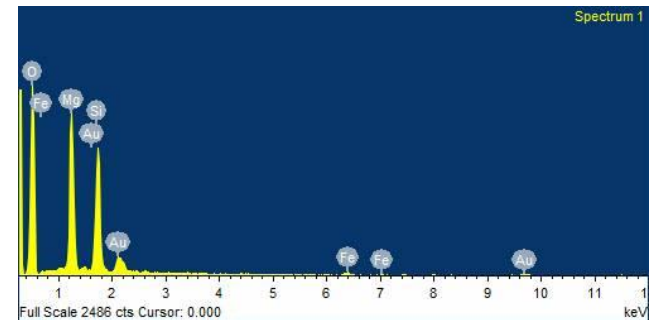

b) EDX of chrysotile (analysis 1)

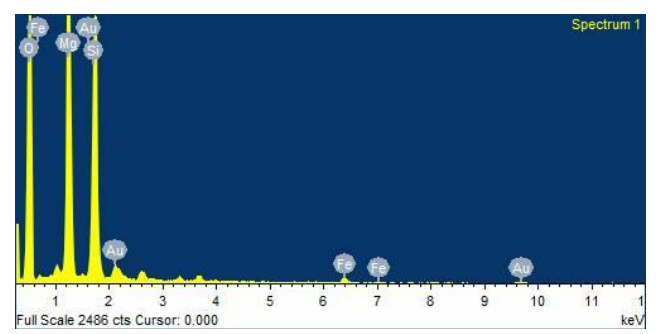

d) EDX of chrysotile (analysis 2)

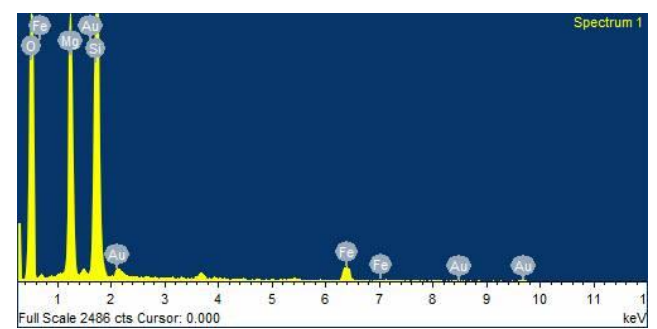

f) EDX of chrysotile (analysis 3)

Fig. 5. SEM image and EDX spectrum of chrysotile from sample 3 
T a b l e 1

Chemical composition of chrysotile from samples 1-3 by SEM-EDX

\begin{tabular}{lccc:|ccc|ccc}
\hline \hline Element & \multicolumn{3}{c}{ Sample 1 } & \multicolumn{3}{c}{ Sample 2 } & \multicolumn{3}{|c}{ Sample 3 } \\
\hdashline $\mathrm{O}$ & 64.61 & 67.65 & 62.50 & 65.91 & 66.81 & 64.88 & 67.47 & 62.61 & 62.37 \\
$\mathrm{Mg}$ & 20.27 & 18.68 & 20.64 & 20.41 & 20.00 & 20.42 & 18.27 & 21.08 & 14.74 \\
$\mathrm{Si}$ & 14.24 & 12.55 & 15.58 & 13.16 & 13.19 & 14.13 & 13.12 & 15.41 & 20.21 \\
$\mathrm{Fe}$ & 0.88 & 1.12 & 1.29 & 0.52 & - & 0.56 & 1.15 & 0.90 & 2.68 \\
\hdashline Total & 100.00 & 100.00 & 100.00 & 100.00 & 100.00 & 100.00 & 100.00 & 100.00 & 100.00 \\
\hline \hline
\end{tabular}

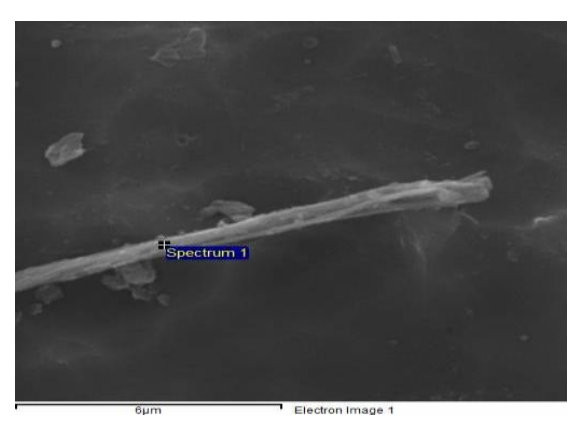

a) SEM image of chrysotile (analysis 1)

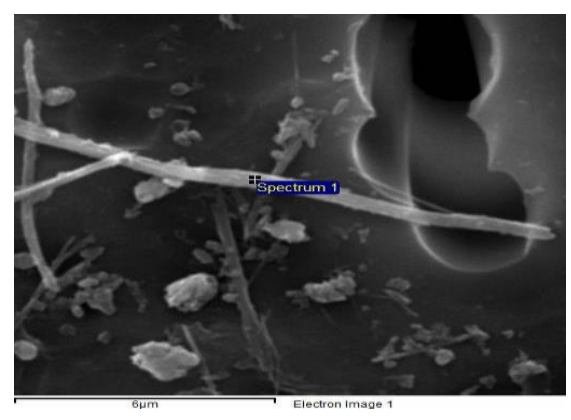

c) SEM image of chrysotile (analysis 2)

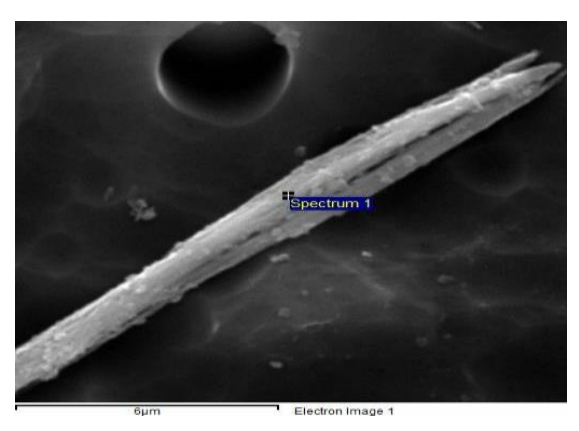

e) SEM image of chrysotile (analysis 3)

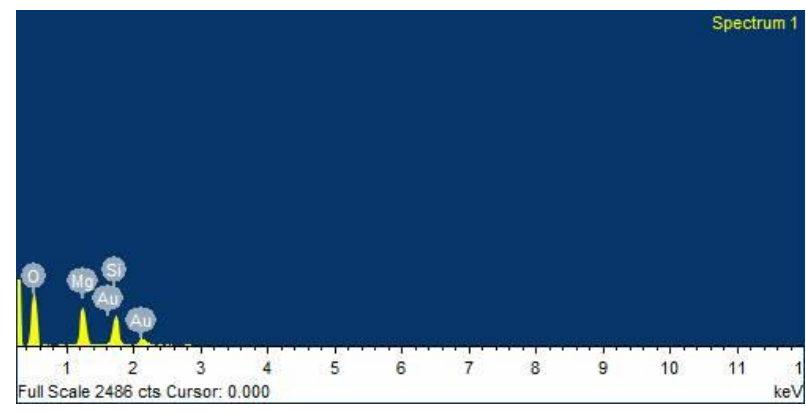

b) EDX of chrysotile (analysis 1)

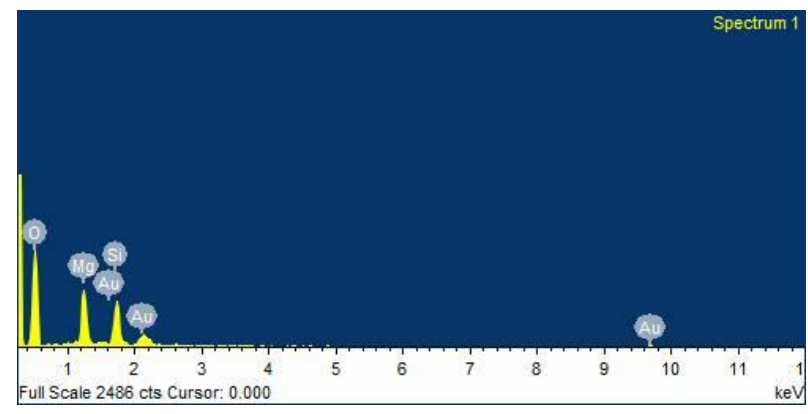

d) EDX of chrysotile (analysis 2)

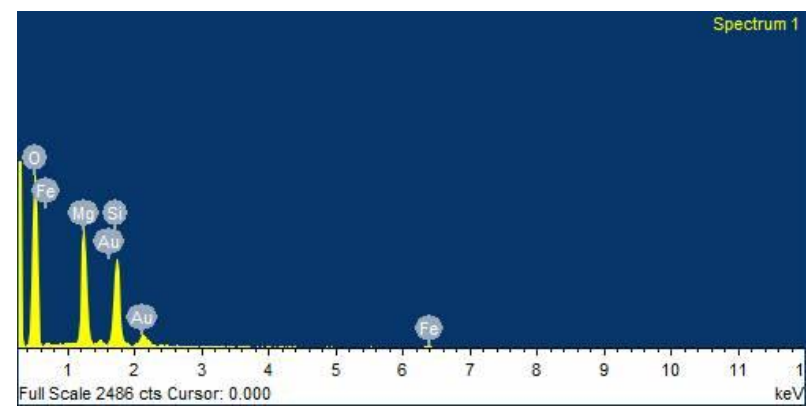

f) EDX of chrysotile (analysis 3)

Fig. 6. SEM image and EDX spectrum of chrysotile from sample 4

SEM image and EDX spectrum for sample 5 are given in Figure 7 and chemistry is given in Table 2. From Table 2 can be seen that there is a presence of Fe (2.03 wt $\%)$ only in one spectrum. Chrysotile fibers are long 19-351 $\mu \mathrm{m}$ and wide from $0.56 \mu \mathrm{m}$ on individual fibers to $5 \mu \mathrm{m}$ on bundles. 


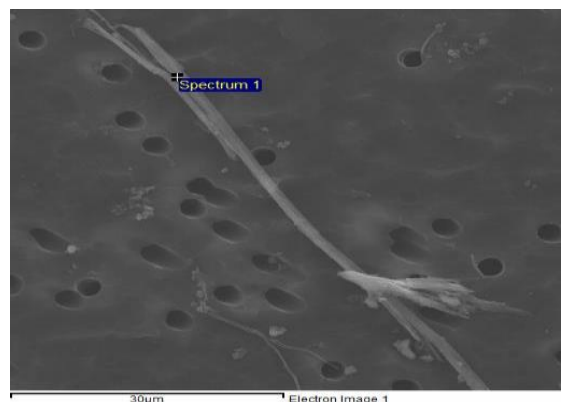

a) SEM image of chrysotile (analysis 1 )

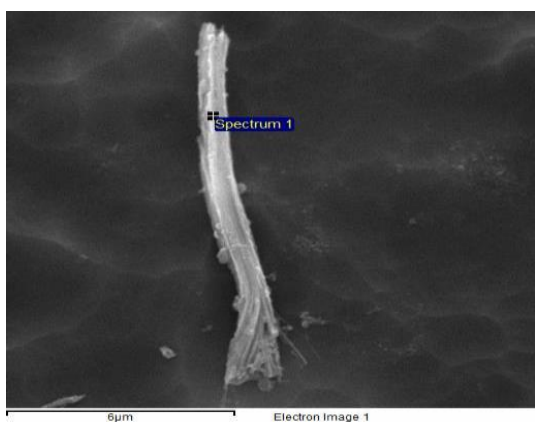

e) SEM image of chrysotile (analysis 2)

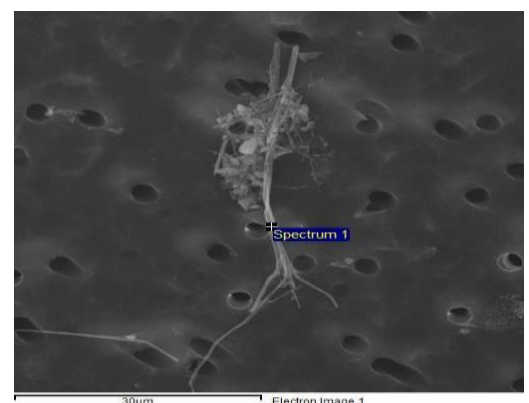

g) SEM image of chrysotile (analysis 3)

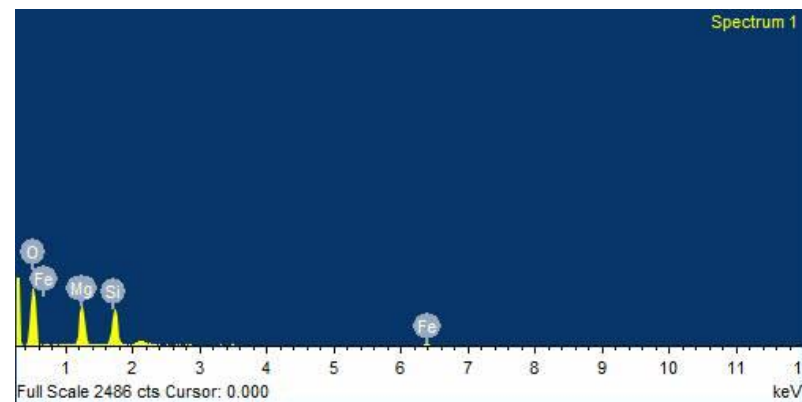

b) EDX of chrysotile ( analysis1)

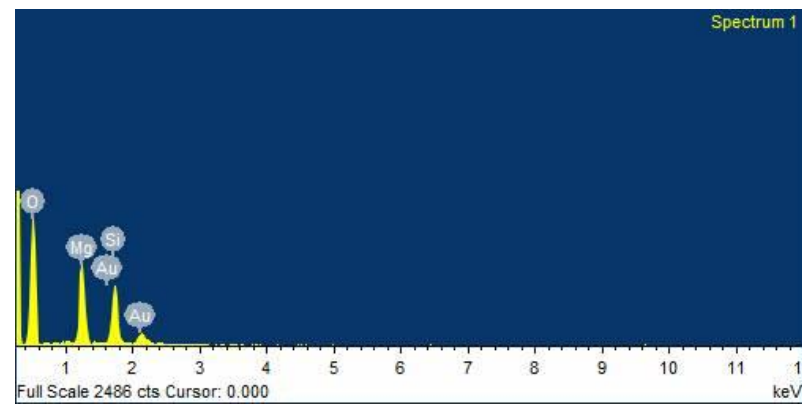

f) EDX of chrysotile (analysis 2)

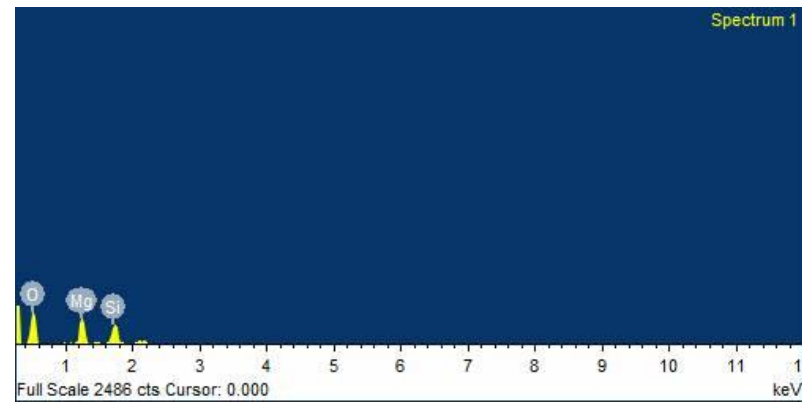

h) EDX of chrysotile ( analysis 3)

Fig. 7. SEM image and EDX spectrum of chrysotile from sample 5

T a b l e 2

Chemical composition of chrysotile from samples 4 and 5 by SEM-EDX

\begin{tabular}{c|ccc|ccc}
\hline \hline Element & \multicolumn{3}{|c|}{ Sample 4 } & \multicolumn{3}{c}{ Sample 5 } \\
\hline $\mathrm{O}$ & 71.30 & 74.48 & 71.34 & 69.38 & 73.22 & 69.35 \\
$\mathrm{Mg}$ & 16.73 & 15.06 & 16.62 & 15.85 & 16.36 & 18.07 \\
$\mathrm{Si}$ & 11.97 & 10.47 & 11.17 & 12.74 & 10.42 & 12.58 \\
$\mathrm{Fe}$ & - & - & 0.87 & 2.03 & - & - \\
\hline Total & 100.00 & 100.00 & 100.00 & 100.00 & 100.00 & 100.00 \\
\hline \hline
\end{tabular}

The chemical composition, crystal structure and polytypic forms of the serpentine minerals have been described by Langer \& Nolan (1986, 1994), Virta, R. L. (2002). Chrysotile exhibits a smaller variation in chemical composition than other (nonasbestiform) serpentine minerals (lizardite and antigorite).
The idealized chemical formula of chrysotile is $\mathrm{Mg}_{3}\left(\mathrm{Si}_{2} \mathrm{O}_{5}\right)(\mathrm{OH})_{4}$, substitution by other elements in the crystal structure is possible. According to Skinner et al. (1988) substitution possibilities are:

$$
\left(\mathrm{Mg}_{3-\mathrm{x}-\mathrm{y}} \mathrm{R}_{\mathrm{x}}{ }^{+2} \mathrm{R}_{\mathrm{y}}{ }^{+3}\right)\left(\mathrm{Si}_{2-\mathrm{y}} \mathrm{R}_{\mathrm{y}}{ }^{+3}\right) \mathrm{O}_{5}(\mathrm{OH})_{4} \text {. }
$$

where $\mathrm{R}^{2+}=\mathrm{Fe}^{2+}, \mathrm{Mn}^{2+}, \mathrm{Ni}^{2+}$ and $\mathrm{R}^{3+}=\mathrm{Al}^{3+} \mathrm{Fe}^{3+}$. 
The most common substitutions are $\mathrm{Si}^{4+} \rightarrow \mathrm{Al}^{3+}, \mathrm{Mg}^{2+} \rightarrow \mathrm{Fe}^{2+}$, and $\mathrm{Mg}^{2}+\rightarrow \mathrm{Al}^{3+}$. However, these substitutions typically represent much less than $10 \%$ of the atomic sites (Veblen and Wylie 1993). Other metal substitutions (such as $\mathrm{Ni}, \mathrm{Co}$, $\mathrm{Mn}, \mathrm{Cr}$ and $\mathrm{Zn}$ ) may occur in trace amounts (Ross 1981, 2003).

Cation substitution in chrysotile is typically more limited than in the other magnesium-serpentine minerals (lizardite and antigorite).

In examined samples from Bogoslovec have substitution of $\mathrm{Mg}^{2+} \rightarrow \mathrm{Fe}^{2+}$. Concentration of $\mathrm{Fe}^{2+}$ is in range up 0.52 to $2.68 \mathrm{wt} \%$.

XRD patterns on investigated samples are given in Figure 8. The most intense registered maxima in the studied powder pattern area compared with the corresponding maxima of chrysotile $(\mathrm{Chr})$ ICDD 000100381 and antigorite (Ant) ICDD 01 0743134.
The unit cell parameters obtained using the main reflection lines of $X$-ray diffraction on sample 2 are: $\mathrm{a}=5.330 \AA ; \mathrm{b}=9.156 \AA ; \mathrm{c}=14.665 \AA ; \beta=$ $93.432^{\circ} ; \mathrm{V}=714.550 \AA^{3}, \mathrm{Z}=2$.

Although Padurow (1950) suggested a triclinic structure for chrysotile, it is thought at present that the principal form of chrysotile is clino-chrysotile, while ortho- and parachrysotile are less common Whittaker \& Zussman, (1956).

According to researches (Whittaker, 1951; Jagodzinski \& Kunze, 1954; Whittaker, 1955, 1956a,b,c, 1957; Whittaker \& Zussman, 1956) at chrysotile exist morphological and structural variations.

Table 6 gives a comparison of unit cell data on the examined chrysotile with data reported by Simone Pollastri et al. (2016).

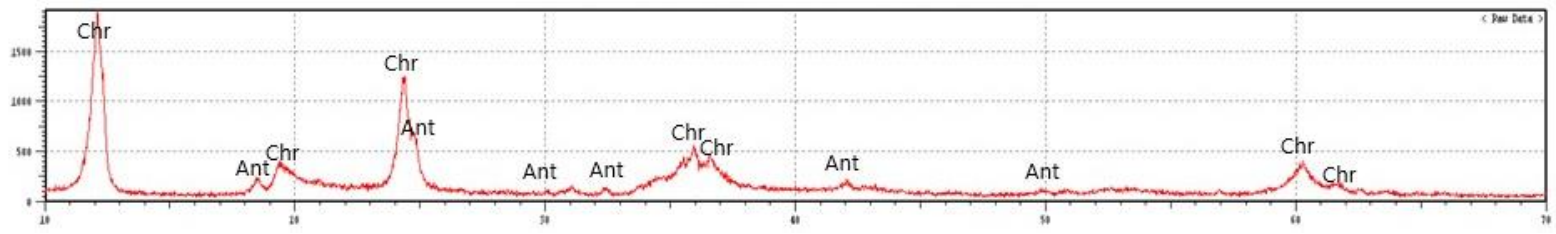

a)

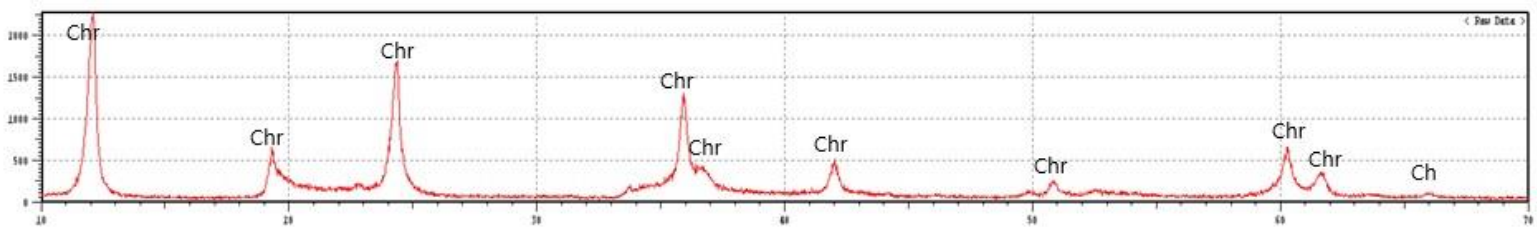

b)

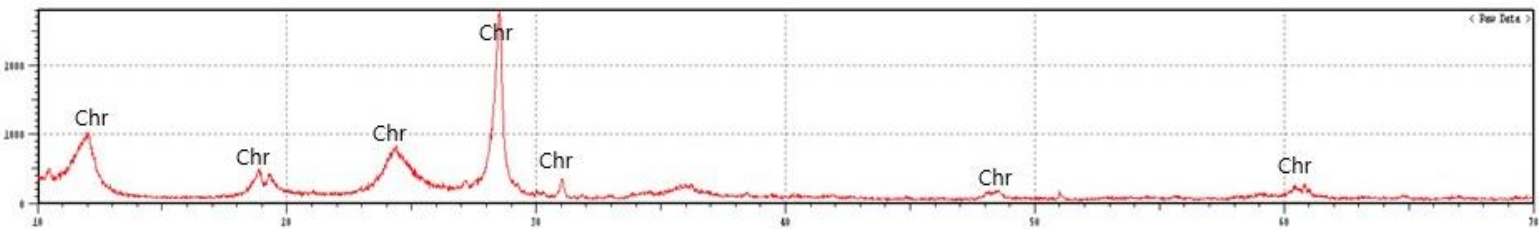

c)

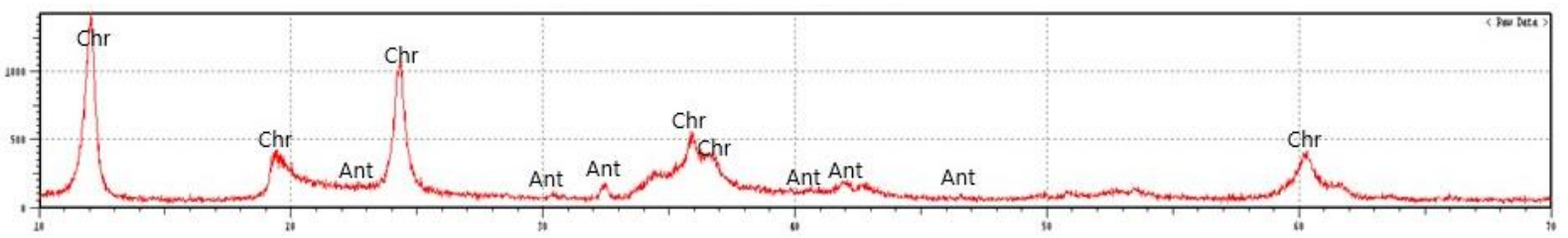

d)

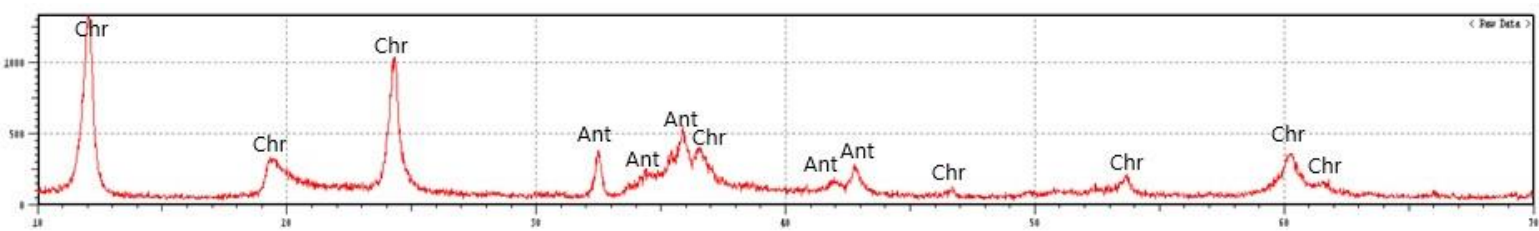

e)

Fig. 8. XRD pattern of the samples: a) sample 1; b) sample 2; c) sample 3; d) sample 4; e) sample 5 
Table 6

Comparison of unit cell data on the examined chrysotile with data reported by Simone Pollastri et al. (2016) and W. A. Deer et al. (1962)

\begin{tabular}{ccccccc}
\hline \hline & $\begin{array}{c}\text { Bogoslovec } \\
\text { (North Macedonia) }\end{array}$ & $\begin{array}{c}\text { American mineralogist } \\
\text { crystal structure database } \\
\text { Falini et al., 2004 }\end{array}$ & $\begin{array}{c}\text { UICC standard chrysotile asbestos } \\
\text { "B" Canadian (NB \#4173-111-1) } \\
\text { from Quebec, Canada }\end{array}$ & $\begin{array}{c}\text { Balangero } \\
\text { (Turin, Italy) }\end{array}$ & $\begin{array}{c}\text { Valmalenco } \\
\text { (Sondrio, Italy) }\end{array}$ & $\begin{array}{c}\text { Deer } \\
\text { et.al.,1962 }\end{array}$ \\
\hline $\mathrm{a}$ & 5.330 & 5.340 & 5.354 & 5.394 & 5.348 & 5.34 \\
$\mathrm{~b}$ & 9.156 & 9.241 & 9.155 & 9.204 & 9.23 & 9.25 \\
$\mathrm{c}$ & 14.665 & 14.689 & 14.735 & 14.553 & 14.717 & 14.65 \\
$\beta$ & 93.432 & 93.66 & 93.60 & 94.10 & 93.96 & 93.25 \\
$\mathrm{~V}$ & 714.550 & 723.379 & & & & \\
\hline \hline
\end{tabular}

It is important to note that the UICC chrysotile sample is actually a mixture of fibers from the brands Bells, Carey, Cassair, Flintkote, Johns-
Manville Lake, Normandie and National, proportioned to roughly be representative of Canadian asbestos production at that time.

\section{CONCLUSION}

Summarizing available data from this study, we concluded that the investigated samples are chrysotile. It occurs as compact veins in the serpentinites. Sometimes fiber veins split up in several smaller veins or coalesce and form a larger vein. Fibrous crystals of chrysotile are with different size (long from 17 to $390 \mu \mathrm{m}$ and width from 0.35 on individual fibers to $30 \mu \mathrm{m}$ on bundles). Individual chrysotile fibers are white and silky, but the colour of the aggregate in veins is usually ligh yellow to light green. The luster is silky. Crystal system is monoclinic-prismatic. Point group $2 / \mathrm{m}$. Streak is white.

From numerous descriptions on different localities, it is clear that chrysotile occurs preferentially in serpentinites that have undergone some degree of recrystallization, in which the serpentine minerals have begun to form interlocking textures. It is generally less clear whether the driving force for this recrystallization is an increase in temperature, or the onset of deformation opening cracks that can hold aqueous fluid and serve as pathways for the movement of fluids, or possibly both.

The development of chrysotile veins illustrates the mobility of the major elements $\mathrm{Mg}, \mathrm{Fe}$ and $\mathrm{Si}$ during serpentinization.

In examined samples from Bogoslovec have substitution of $\mathrm{Mg}^{2+} \rightarrow \mathrm{Fe}^{2+}$. Concentration of $\mathrm{Fe}^{2+}$ is in range up 0.52 to $2.68 \mathrm{wt} \%$.

The unit cell parameters obtained using the main reflection lines of $\mathrm{X}$-ray diffraction on sample 2 are: $\mathrm{a}=5.330 \AA$; $\mathrm{b}=9.156 \AA$; $\mathrm{c}=14.665 \AA ; \beta=$ 93.432 $; \mathrm{V}=714.550 \AA^{3}$

\section{REFERENCES}

Adžigogov, L. (1967): Elaborate of Mining Reserves of Asbestos of Bogoslovec. Papers of the Geological Institute of SRM.

Deer, W. A., Howie, R. A. and Zussman, J. (1962): Rocks Forrming Minerals: Vol. 1-5. Longmans, Green \& Co., London.

Dumurdžanov, N., Hristov, S., Ivanova, V., Pavlovski, B., (1965): Explanatory note of the General Geological Map of SFRJ, Sheet Stip, scale 1:100 000. Skopje, R. Macedonia.

Falini, G., Foresti, E., Gazzano, M., Gualtieri, A. F., Leoni, M., Lesci, I. G., Roveri, N. (2004): Chemistry - A European Journal, 10, 3043-3049.
Holland, T., Redfern, S. (1997, new version April 2006): Unit cell refinement from powder diffraction data: the use of regression diagnostics. Mineralogical Magazine, 61, 6577.

Jagodziński, H. Y., Kunze, G. (1954): Neues Jb. Min. Mh, p. 137.

Langer, A. M., Nolan, R. P. (1986): The properties of chrysotile as determinants of biological activity. In: Wagner C. (ed.) The biological effects of chrysotile. Accomplished Oncol, 1, 30-51.

Langer, A. M., Nolan, R. P. (1994): Chrysotile: its occurrence and properties as variables controlling biological effects. Ann Occup Hyg, 38427-38441. 
Padurow, N. N. (1950): Über die Strukturzelle von Chrysotilasbest, Acta Cryst. 3, 204.

Pavlovik, S. (1951): Report of Asbestos in Macedonia - Bogoslovec, Papers of the Geological Institute of SRM. Skopje.

Pollastri, S., Perchiazzi, N., Lezzerini, M., Plaisier, J. R., Cavallo, A., Dalconi, M. C., Gandolfi, N. B., Gualtieri, A. F. (2016): The crystal structure of mineral fibers. 1: Chrysotile, Periodico di Mineralogia, 85 (3), pp. 249-259. DOI: $10.2451 / 2016 \mathrm{PM} 655$

Pooley, F. D, (1987): An examination of the fibrous minerals, Pub Med, 583-588.

Ross, M. (1981): The geologic occurrences and health hazards of amphibole and serpentine asbestos. Reviews in Mineralogy and Geochemistry, 9A: 279-323.

Ross, M. and Nolan, R. P. (2003) History of asbestos discovery and use and asbestos-related disease in context with the occurence of asbestos within ophiolite complexes. DOI: https://doi.org/10.1130/0-8137-2373-6.447. In: Dilek, Y. (ed.) and Newcomb, S. (ed): Ophiolite Concept and the Evolution Geological Thought. Geological Society of America Special Paper. pp. 195-207.

Skinner, H. C. W., Ross, M., Frondel, C. (1988): Asbestos and Other Fibrous Materials: Mineralogy Crystal Chemistry, and Health Effects. Oxford University Press, pp. 1-215.

Veblen, D. R., Wylie, A. G. (1993): Mineralogy of amphiboles and 1:1, layer silicates. Reviews in Mineralogy Geochemistry, 28, 61-138.
Virta, R. L. (2002): Asbestos: Geology, Mineralogy, Mining, and Uses. Tech. rep. U.S. Geological Survey Open-File Report 02-149 Version 1.0, p. 28.

Whittaker, E. J. W. (1951): An orthorhombic variety of chrysotile, Acta Cryst. 4, 187.

Whittaker, E. J. W. (1955): The structure of chrysotile I: Acta Cryst. 8, 571 .

Whittaker, E. J. W. (1956a): The structure of chrysotile II: Clinochrysotile, Acta Cryst. 9, 855.

Whittaker, E. J. W. (1956b): The structure of chrysotile III: Orthochrysotile, Acta Cryst. 9, 862.

Whittaker, E. J. W. (1956c): The structure of chrysotile IV: Parachrysotile, Acta Cryst. 9, 865.

Whittaker, E. J, W. (1957): The structure of chrysotile V: Diffuse reflexions and fibre texture. Acta Crystallographica, 10 (Part 3), 149-156.

Whittaker, E. J. W., Zussman, J. (1956): The structure of chrysotile, Miner. Mag. 31, 107.

Wicks, F. J., O’Hanley, D. S., (1988): Serpentine minerals: Structures and petrology, in Bailey, S. W.ed., Hydrous phyllosilicates other than micas: Mineralogical Society of America, Reviews in Mineralogy, Vol. 19, pp. 295-346.

Wicks, F. J., Plant, A. G. (1979): Electron-microprobe and Xray-microbeam studies of serpentine textures: Canadian Mineralogist, Vol. 17, pp. 785-830.

Woodroofe, H. M. (1956): Pyrolysis of chrysotile asbestos fibre. Trans Can Inst Min \& Met, 59, 363-368.

\title{
Р е 3 и м е
}

\section{МИНЕРАЛОШКИ КАРАКТЕРИСТИКИ НА ХРИЗОТИЛ ОД БОГОСЛОВЕЦ, СЕВЕРНА МАКЕДОНИЈА}

\author{
Тена Шијакова-Иванова, Иван Боев, Ѓорѓи Димов

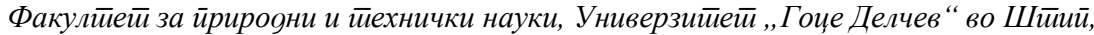

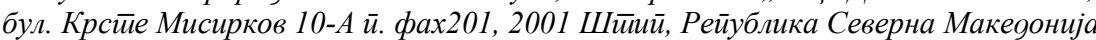 \\ tena.ivanova@ugd.edu.mk
}

Клучни зборови: хризотил; скенирање со електронски микроскоп; рендгенски дифрактометар

Сумирајќи ги податоците од ова истражување, заклучивме дека испитуваните примероци се хризотил. Хризотилот се јавува како компактни жили во серпентинитот. Хризотилните жили се широки од $99 \mu \mathrm{m}$ до неколку милиметри. Развојот на хриозотилните жили ја илустрира подвижноста на главните елементи $\mathrm{Mg}, \mathrm{Fe}$ и $\mathrm{Si}$ за време на серпентинизацијата. Хризотилните влакна се со различна големина (должина од 17 до $390 \mu \mathrm{m}$ и ширина од. 0,35 $\mu \mathrm{m}$ кај одделните влакна до $30 \mu \mathrm{m}$ кај сноповите). Влакната се ориентирани нормално на жилите. Во испитуваните примероци од Богословец има замена на $\mathrm{Mg}^{2+} \rightarrow \mathrm{Fe}^{2+}$. Концентрацијата на $\mathrm{Fe}^{2+}$ е во опсег од 0,52 до $2,68 \%$. Со добиените податоци од рендгенските дифракциони испитувања за примерокот бр. 2 се пресметани димензиите на елементарната ќелија. Добиени се следниве резултати: $\mathrm{a}=5.330 \AA$; $\mathrm{b}$ $=9,156 \AA ; \mathrm{c}=14.665 \AA ; \beta=93.432^{\circ} ; \mathrm{V}=714.550 \AA^{3}$. кои се во целосна согласност со литературните податоци. 